\title{
The Effect of Alpha Lipoic Acid on Cerebrospinal Fluid Biochemistry and Brain Edema After Experimental Traumatic Brain Injury
}

\author{
Halil KUL ${ }^{1}$, Haydar CELIK², Adem KURTULUS ${ }^{3}$, Ayhan TEKINER ${ }^{2}$, Yavuz ERDEM², Gulnur KUL ${ }^{4}$, \\ Mehmet Akif BAYAR ${ }^{2}$ \\ ${ }^{1}$ Hatay State Hospital, Department of Neurosurgery, Hatay, Turkey \\ ${ }^{2}$ University of Health Sciences, Ankara Training and Research Hospital, Department of Neurosurgery, Ankara, Turkey \\ ${ }^{3}$ Afyonkarahisar State Hospital, Department of Neurosurgery, Afyonkarahisar, Turkey \\ ${ }^{4}$ Kirikhan State Hospital, Department of Infectious Diseases, Hatay, Turkey
}

Corresponding author: Halil KUL drhalilkul@gmail.com

\section{ABSTRACT}

AIM: To investigate the effect of alpha lipoic acid on cerebrospinal fluid (CSF) osmolarity and brain tissue water ratio in a rabbit model of traumatic brain injury.

MATERIAL and METHODS: Using a previously established model of traumatic brain injury using liquid nitrogen, 36 New Zealand rabbits were randomized into six groups (three treatment groups, a no trauma/no treatment group, a trauma/no treatment group, and a no trauma/treatment group). The treatment groups were administered intravenous alpha lipoic acid at different times of the experiment. Cerebrospinal fluid was obtained 96 hours after injury/treatment via cisterna magna puncture; glucose, blood urea nitrogen, and sodium levels were measured and osmolarity was calculated. Brain tissue water ratio was determined using wet and dry brain weights. The therapeutic effect of alpha lipoic acid was evaluated by comparing cerebrospinal fluid osmolarity and brain tissue water ratio between study groups.

RESULTS: Based on cerebrospinal fluid osmolarity values, alpha lipoic acid treatment effectiveness was greatest in the group that received 3 doses after trauma.

CONCLUSION: Alpha lipoic acid is effictive in the treatment of brain edema after experimental traumatic brain injury.

KEYWORDS: Alpha lipoic acid, Brain edema, Traumatic brain injury, Rabbits

\section{INTRODUCTION}

$\mathrm{B}$ rain edema is one of the main causes of morbidity and mortality in traumatic brain injury (TBI) patients aged 1-44 years. The mortality of severe TBI ranges between $30 \%-70 \%(5,13,23,28)$. The pathology associated with TBI can be divided into primary and secondary brain injuries. Primary injury is associated with mechanical motion at the time of injury, whereas secondary injury is caused by a complex physiologic and biochemical cascade in response to the initial injury that is not fully understood $(3,20)$. Although they have significant effects on tissue necrosis and progressive neuronal cell death after TBI, the secondary mechanisms of delayed post-traumatic neuronal cell death remain unclear.

The ideal hyperosmolar agent for treating elevated intracranial pressure (ICP) $(>20 \mathrm{~mm} \mathrm{Hg})$ in patients with TBI and the method of administration remains under debate. Hyperosmolar treatment is typically instituted to optimize cerebral blood flow and improve tissue oxygenation of the
Halil KUL (1) : 0000-0002-6168-7462

Haydar CELIK (1): 0000-0002-2702-5457

Adem KURTULUS (1) : 0000-0002-8084-1015
Ayhan TEKINER (1): 0000-0002-3835-2568

Yavuz ERDEM (1) : 0000-0002-4446-9228

Gulnur KUL (1) : 0000-0001-7317-3461
Mehmet Akif BAYAR (D) : 0000-0002-4285-9476 
Kul H. et al: The Role of Alpha Lipoic Acid in Traumatic Brain Injury

injured brain after nonpharmacologic treatments and sedation have been optimized $(7,24,25)$. Free oxygen radicals and lipid peroxidation are believed to play an important role in secondary brain damage $(10,17)$. The increase in lipid peroxidation end products after head trauma and protective effect of free radical collectors and lipid antioxidants found in previous studies support this idea $(16,17)$.

Mitochondrial dysfunction has an important role in the harmful effects of reactive oxygen species. Minimizing these effects by protecting mitochondrial function is a therapeutic goal. Glutathione (GSH), a complex molecule consisting of cysteine, glycine, and glutamate, is believed to be one of the most important antioxidants in living organisms. Alpha lipoic acid (A-LA), first defined as a coenzyme in the tricarboxylic acid cycle (Krebs cycle) in $1951(1,18)$, is a thiol derivative involved in regenerating GSH (26-28) and neutralizing reactive oxygen species. Additional properties include rapid absorption, antioxidant effect of reduced and oxidized forms, solubility in both liquid and lipid phases, and ability to chelate with free metal ions. Therefore, A-LA has been described as "ideal," "unique," and the "universal antioxidant" $(14,18,21,29)$. Lipid peroxidation of A-LA and its effect on antioxidant levels has been studied in various brain regions of young and elderly rats; when applied for 7 and 14 days at a dose of $100 \mathrm{mg} / \mathrm{kg}$, A-LA significantly reduced lipid peroxidation and increased antioxidant levels (2). In this experimental study, the effect of A-LA on brain edema after cerebral trauma in rabbits was investigated. We hypothesized that A-LA would reduce interstitial brain edema.

\section{MATERIAL and METHODS}

This study was conducted at the Ankara Training and Research Hospital Experimental Animals Laboratory. Thirty-six New Zealand rabbits, all male and ranging in weight from 2.2 to $2.6 \mathrm{~kg}$, were used as experimental subjects. The animals were taken care of according to the relevant provisions of the Helsinki Final Acts and the principles set forth by the United States National Health Institute; they were fed with standard animal feed, given adequate amounts of water, and spent 12 hours in an open environment and 12 hours in an indoor environment. Head trauma induction, cisterna magna puncture, and animal sacrifice were performed in the same laboratory. Thirty-six new Zealand rabbits included in the experiment were randomized into 6 different groups. Alpha lipoic acid was administered to these groups at a dose of 100 $\mathrm{mg} / \mathrm{kg}$ intravenously at 4-24 and 72 hours. Determination of cerebrospinal fluid (CSF) biochemistry and osmolarity and brain tissue water ratio was conducted in laboratories of the Ankara Training and Research Hospital. A microscope and microsurgery tools were used during the surgical procedures and decapitation. Study approval was obtained from the Local Ethics Committee for Animal Experiments of University of Health SciencesAnkara Training and Research Hospital (approval number 0039, date 26.05.2017).

\section{Experimental Groups}

Rabbits were randomized into six groups as follows:
Group 1/Control (C)-craniectomy was performed but no head trauma or treatment

Group 2 (T1) -craniectomy was performed, head traumatized but not treated, then sacrificed 96 hours later

Group 3 (T2) - craniectomy was performed, head traumatized, single dose treatment 4 hours following trauma, then sacrificed 96 hours later

Group 4 (T3) - craniectomy was performed, head traumatized, two dose treatment 4 hours and 24 hours following trauma, then sacrificed 96 hours later

Group 5 (T4) - craniectomy was performed, head traumatized, three dose treatment 4 hours, 24 hours, and 72 hours following trauma, then sacrificed 96 hours later

Group 6 (T0) - craniectomy was performed, no head trauma, three dose treatment 4 hours, 24 hours, and 72 hours following trauma, then sacrificed 96 hours later

\section{Anesthesia}

Prior to the surgical procedure, all rabbits were anesthetized with $35 \mathrm{mg} / \mathrm{kg}$ of intramuscular $5 \%$ ketamine hydrochloride (Eczacibasi Pharmaceutical Industry, Istanbul, Turkey) and $1.5 \mathrm{mg} / \mathrm{kg}$ of intramuscular $2 \%$ xylazine (Rompun ${ }^{\oplus}$; Bayer, Leverkusen, Germany) $1.5 \mathrm{mg} / \mathrm{kg}$. Additional dosages were given as needed. Oxygen saturation, heart rate, and systolic, diastolic, and mean arterial blood pressure were continuously monitored; body temperature was measured with a rectal probe. Four subjects died during the experimental procedure and were replaced with new rabbits.

\section{Cisterna Magna Puncture}

The subjects were positioned in the lateral reclined position on a flat surface after anesthesia was administered. Using the technigue described by Joshita et al., the head was brought into a hyperflexed position and cisterna magna puncture was performed with a butterfly needle in the atlanto-occipital region (11). Alpha lipoic acid was administered to the subjects at different hours following traumatic brain injury. Immediately before the 96 hours following the injury, one ml CSF was taken from each subject and sacrificed.

\section{Surgical Procedure and Head Trauma Induction}

The subjects were positioned prone while under anesthesia and an approximately $4 \mathrm{~cm}$ median vertical incision was performed over the frontoparietal region extending to both sides, exposing the midline and the right coronal suture. The periosteum was elevated and the right temporalis muscle was severed from its adhesion point and released over the temporal bone. Then a craniectomy in the middle of the right parietal bone was performed without violating dural integrity using a dental tour. The craniectomy was enlarged to an area of $15 \mathrm{~mm} \times 15 \mathrm{~mm}$ using hemostatic forceps with a curved tip (Classic ${ }^{\circledR}$ forceps, Adson hemostatic, curved, delicate, 304464; Codman, Raynham, MA, USA) and rongeur. The dura was left intact in order to protect the cerebral cortex from damage. An aluminum probe (4 $\mathrm{mm}$ tip), cooled to -150 in liquid N2, was placed against the dura overlying the right 
cerebral cortex of anesthetized rabbit. So, head trauma was induced in the subjects of the trauma groups. $(11,12,19,21)$. Mechanical respiration support was provided to the subjects as needed until regular breathing resumed.

\section{Perfusion, Sacrifice, and Tissue Harvesting}

Subjects in all groups were anesthetized again with the same method after 96 hours. Thoracotomy was performed and 1000 $\mathrm{mL}$ of $0.9 \%$ sodium chloride was administered under $100 \mathrm{~mm}$ $\mathrm{Hg}$ of pressure via a catheter relayed from the left ventricle to the aorta. The right atrium was opened and the physiological saline was withdrawn. Perfusion continued until the fluid was clear. Then, the subjects were sacrificed by decapitation. The scalp was opened and craniotomy was performed to remove the brain and brain stem in entirety. A microscope and microsurgical instruments were used to obtain tissue samples $(3 \mathrm{~mm} \times 3 \mathrm{~mm} \times 3 \mathrm{~mm}$ ) from the right hemisphere where trauma was induced as well as the opposite hemisphere.

\section{Evaluation of Treatment Effectiveness}

\section{Determination of CSF biochemistry and osmolarity}

The effect of A-LA on CSF osmolarity was examined in the CSF samples taken via cisterna magna puncture. Glucose, blood urea nitrogen (BUN), and sodium levels were measured, and osmolarity values were calculated. In the calculation of CSF osmolarity, 2x Na + glucose / $18+\mathrm{BUN} / 2.8$ formula was used.

\section{Determination of brain tissue water ratio}

In order to determine post-traumatic brain edema and treatment effectiveness, brain tissue water ratios were determined in each subject. The tissue samples were quickly weighed after tissue harvesting with pre-determined and numbered aluminum papers and recorded. Immediately after weighing, the samples were incubated at $105^{\circ} \mathrm{C}$ for 48 hours in a laboratory oven (Memmert, Schwabach, Germany). Dry weights were then measured after incubation. Brain tissue water ratio was calculated from the resulting data using the following formula $(8,12)$ :

$\%$ water ratio of the brain tissue $=\frac{\text { Wet brain weight }(\mathrm{g}) \text { - Dry brain weight }}{\text { Wet brain weight }} \times 100$

\section{Statistical Evaluation}

The brain tissue water ratios were statistically evaluated with the Kruskal-Wallis nonparametric ANOVA test and the MannWhitney U test using SPSS software for Windows, version 9.05 (IBM, Armonk, NY, USA). $\mathrm{p}<0.05$ was considered statistically significant.

\section{RESULTS}

The CSF biochemistry results ( $\mathrm{Na}$, Glucose, and BUN) and calculated osmolarity values of all subjects presented by group are shown in Table I and Figures 1-3. Table II shows that

Table I: CSF Biochemistry Values of the Study Groups

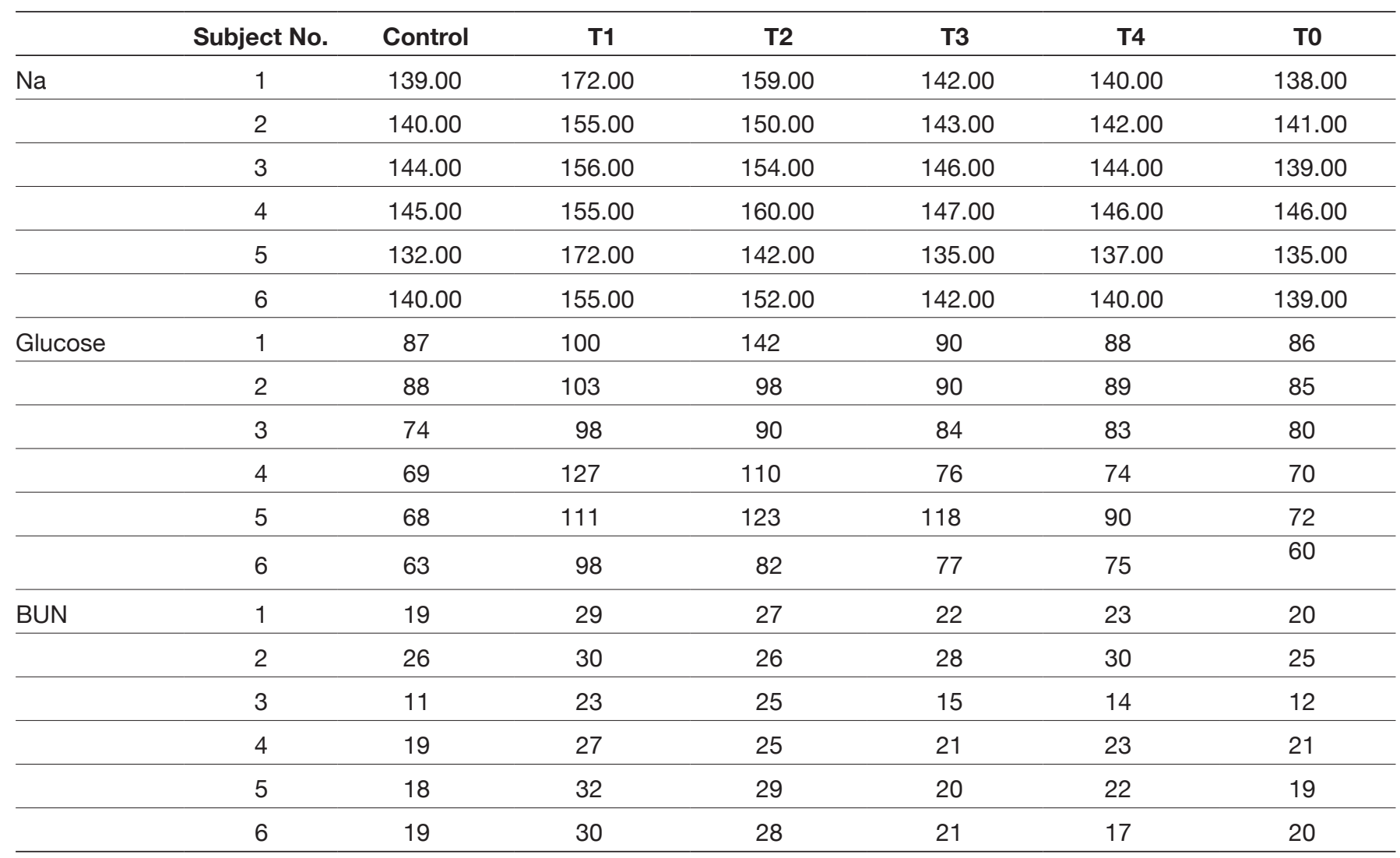


Table II: Osmolarity Results of the Study Groups

\begin{tabular}{ccc}
\hline Osmolarity & Mean \pm SD & Median (min-max) \\
\hline Control & $290.7 \pm 9.12$ & $292(274-300)$ \\
\hline T1 & $337.7 \pm 17.8$ & $326(325-361)$ \\
\hline T2 & $321.9 \pm 14.3$ & $320(301-340)$ \\
\hline T3 & $297.4 \pm 7.6$ & $298(208-305)$ \\
\hline T4 & $295.2 \pm 6.4$ & $295(286-304)$ \\
\hline T0 & $280.4 \pm 7.8$ & $288(280-303)$ \\
\hline
\end{tabular}

osmolarity values were higher in the damaged group, while they were lower in groups administered A-LA without treating or creating trauma. Statistical analysis of the osmolarity values of the study groups shows the following:

1. The difference between the control group and the T1 and T2 groups is significant (all $\mathrm{p}<0.05$ ).

2. The difference between the control group and the T3 and T4 groups is not significant (all p $>0.05$ ).

3. The difference between the T2 group and the control, T3, and TO groups is significant (all $\mathrm{p}<0.05$ ).

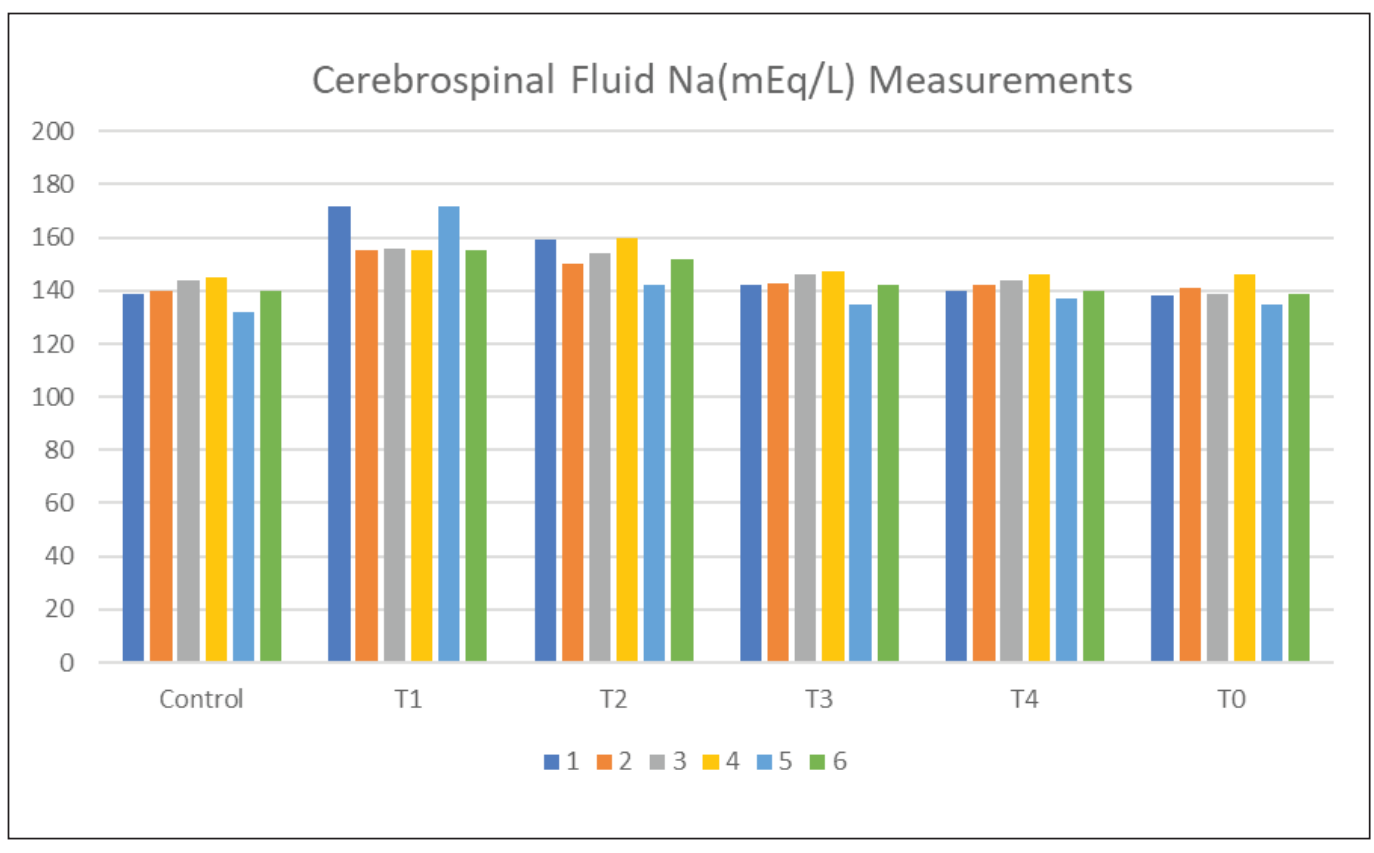

Figure 1: CSF Na values of the study groups.

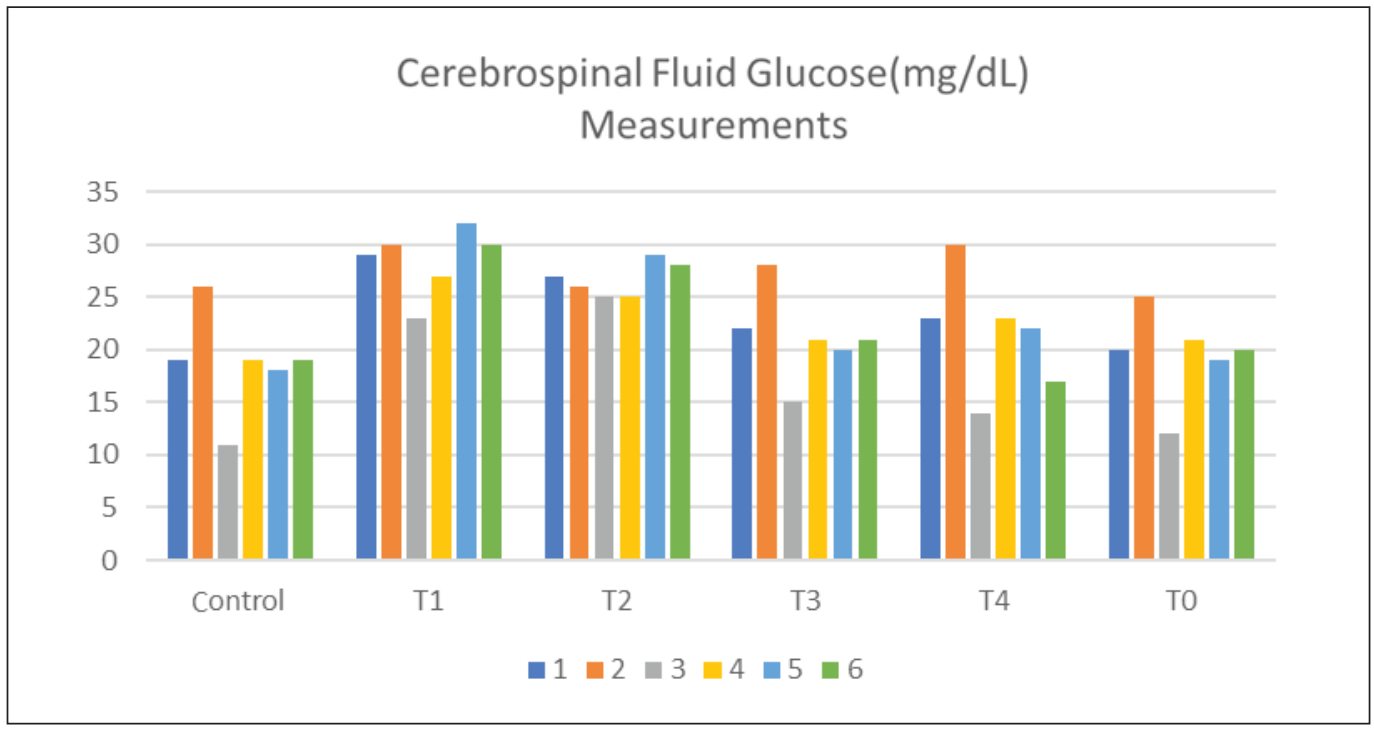

Figure 2: CSF glucose values of the study groups. 
Therefore, A-LA treatment efficacy was greatest in the group that received 3 doses after trauma.

Dry brain weight, wet brain weight, and brain tissue water ratio values of the study groups are shown in Tables III and IV. Table IV demonstrates that wet brain tissue weight was higher in the damaged group while lower in the groups administered A-LA without treating or creating trauma. Statistical analysis of the brain tissue water ratio values shows the following:

1. The difference between the control group and the T1, T2, $\mathrm{T} 3$, and T4 groups is significant (all $\mathrm{p}<0.05)$.

2. The difference between the control and T0 groups is significant $(p<0.05)$.

3. The difference between the T4 and T0 groups is not significant $(p>0.05)$.

4. The difference between the T4 group and the T1, T2, and T3 groups is significant (all $\mathrm{p}<0.05$ ).

This analysis shows a clear difference between the trauma and control groups. With treatment groups, this difference is relatively close to control group.

Table III: Wet Brain Weight Results of the Study Groups

\begin{tabular}{ccc}
\hline Wet weight & Mean \pm SD & Median (min-max) \\
\hline Control & $75.4 \pm 2.14$ & $76(72-78)$ \\
\hline T1 & $82.4 \pm 2.38$ & $83(78-84)$ \\
\hline T2 & $81.5 \pm 1.52$ & $81(79-83)$ \\
\hline T3 & $78.7 \pm 2.66$ & $77(75-82)$ \\
\hline T4 & $77 \pm 2.03$ & $76(74-80)$ \\
\hline T0 & $77.3 \pm 1.52$ & $77(75-79)$ \\
\hline
\end{tabular}

\begin{tabular}{ccc}
\multicolumn{3}{l}{ Table IV: Dry Brain Weight Results of the Study Groups } \\
\hline Dry weight & Mean \pm SD & Median (min-max) \\
\hline Control & - & - \\
\hline T1 & $80.9 \pm 1.23$ & $(79-82)$ \\
\hline T2 & $79.3 \pm 1.9$ & $78(77-82)$ \\
\hline T3 & $77.1 \pm 2.15$ & $76(75-81)$ \\
\hline T4 & $76.4 \pm 2.15$ & $76(74-78)$ \\
\hline T0 & - & - \\
\hline
\end{tabular}

\section{DISCUSSION}

Clinical and laboratory studies of brain edema in recent years have revealed most aspects of its pathophysiology. However, despite this, the treatment of brain edema has not been standardized and it remains a major cause of morbidity and mortality. Many therapeutic principles have been adopted over the years, and accordingly, many different treatment agents have been used. Therefore, studies on this subject and creating an appropriate experimental model are essential.

In our study, we used the model defined by Klatzo in 1958 which induced experimental head trauma by spraying cold nitrogen. An aluminum probe (4 mm tip), cooled to $-150 \sim$ in liquid N2, was placed against the dura overlying the right cerebral cortex of anesthetized rabbit $(19,23)$. We prefer this model because it is effective, easy to apply, and its process of edema development is very similar to human head trauma. When other studies are examined in terms of the brain tissue water ratio; it has been reported that $80 \%$ of gray matter, $68 \%$ of white matter and $75 \%$ of brain water constitute an important part of brain tissue (6). The brain tissue water ratio in cerebral edema is $81 \%-82 \%$ in gray matter and $76 \%-79 \%$ in white matter. Based on these results, the findings of our study

Table IV: Dry Brain Weight Results of the Study Groups

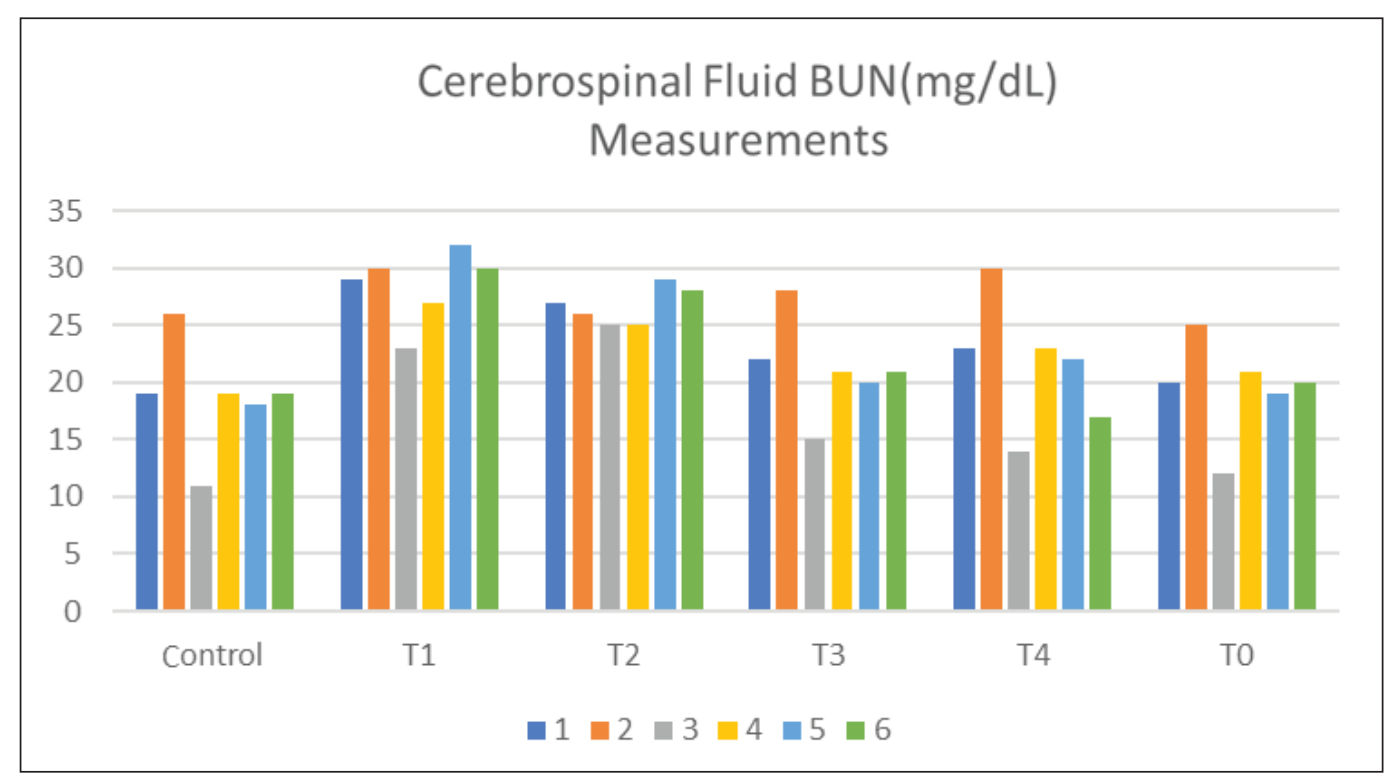

Figure 3: CSF BUN values of the study groups. 
Kul H. et al: The Role of Alpha Lipoic Acid in Traumatic Brain Injury

were found to be consistent with the creation of brain edema. Therefore, our experimental model is suitable for a study of traumatic brain edema.

When we examine the treatment methods and agents that have been used over time, we see that there is no fully active agent. The osmotic treatment applied for this purpose is the fastest and most effective method of reducing tissue water and brain edema $(9,15,22)$ The most widely used agent in osmotherapy today is mannitol. It creates an osmotic pressure difference between the plasma and the brain, allowing edema fluid to pass from the brain to the plasma (30). The use of a physiologically compatible substance in the treatment of traumatic brain edema is very important for the preservation of intra-organism homeostasis. Therefore, we elected to use A-LA in our study. Free radical metabolism is considered an important factor responsible for cellular damage in TBI. While vitamins A, C, and $\mathrm{E}$ and GSH are important nonenzymatic defensive mechanisms against free radical damage, superoxide dismutase (SOD), glutathione peroxidase (GSH-Px), and catalase (CAT) are similarly important enzymatic defense mechanisms within the cell. In post-traumatic reperfusion injury, other factors such as oxygen, blood cells, and complement system activation also lead to tissue damage. Previous studies have shown that polymorphonuclear (PMN) leukocytes have an important role in the formation of cellular damage in reperfusion injury. For the leukocytes to migrate into the tissue, they must be in contact with the endothelium. Active infiltrating neutrophils secrete reactive oxygen radicals and proteases. Intracellular defense mechanisms such as the free radical scavenging SOD and the peroxide-degrading CAT and GSH-Px enzymes are capable of reducing the damage caused by these secreted cytotoxic reactive oxygen metabolites (4). However, these scavenging agents are located within the cell and thought to be inadequate in preventing extracellular damage. Therefore, administering free radical scavenging agents may be a viable treatment option. To investigate this, we evaluated the effect of A-LA administration on CSF osmolarity and brain tissue water ratio in a rabbit model of TBI-induced brain edema. We hypothesized that A-LA would remove free radicals, interact with other antioxidants, repair oxidative damage, and reduce brain edema fluid.

We found a statistically significant difference in CSF osmolarity between the control group and the untreated trauma group (T1), and the control group and the group that received a single-dose A-LA treatment at the $4^{\text {th }}$ hour (T2). However, no significant difference was observed between the control group and the group that received two doses of A-LA treatment at the $4^{\text {th }}$ and $24^{\text {th }}$ hours (T3), nor the group that received three doses of A-LA treatment at the $4^{\text {th }}, 24^{\text {th }}$, and $72^{\text {nd }}$ hours (T4). While the osmolarity values were high in the traumatized group, they were low in the groups given A-LA without creating control, treatment and trauma. Therefore, we concluded that treatment within 4,24 , and 72 hours will be more effective in the first three days.

In the brain tissue water ratio analysis, we observed a statistically significant difference between the control group and the trauma groups ( $\mathrm{T} 1, \mathrm{~T} 2, \mathrm{~T} 3$, and $\mathrm{T} 4)$. In addition, there was a statistically significant difference between the trauma/ no treatment group ( $\mathrm{T} 1)$ and the no trauma/treatment group (T0).

\section{CONCLUSION}

Our results show the efficacy of A-LA treatment in reducing brain edema due to TBI in a rabbit model. Further studies should be performed to obtain dose-response-time data.

\section{REFERENCES}

1. Akpinar D, Yargicoglu P, Derin N, Aliciguzel Y, Sahin M, Agar $A$ : The effect of lipoic acid on lipid peroxidation and visual evoked potentials (VEPs) in rats exposed to chronic restraint stress. Int J Neurosci 117:1691-1706, 2007

2. Arivazhagan P, Panneerselvam C: Effect of DL-a-lipoic acid on neural antioxidants in aged rats. Pharmacol Res 42:219-222, 2000

3. Bramlett HM, Dietrich WD: Pathophysiology of cerebral ischemia and brain trauma: Similarities and differences. J Cereb Blood Flow Metab 24:133-150, 2004

4. Bruce JN, Criscuolo GR, Merrill MJ, Moquin RR, Blacklock JB, Oldfield EH: Vascular permeability induced by protein product of malignant brain tumors: Inhibition by dexamethasone. J Neurosurg 67:880-884, 1987

5. Dehghan F, Hadad MK, Asadikram G, Najafipour H, Shahrokhi $\mathrm{N}$ : Effect of melatonin on intracranial pressure and brain edema following traumatic brain injury: Role of oxidative stresses. Arch Med Res 44:251-258, 2013

6. Feeney DM, Boyeson MG, Linn RT, Murray HM, Dail WG: Responses to cortical injury: I. Methodology and local effects of contusions in the rat. Brain Res 211:67-77, 1981

7. Forsyth LL, Liu-DeRyke X, Parker Jr D, Rhoney DH: Role of hypertonic saline for the management of intracranial hypertension after stroke and traumatic brain injury. Pharmacother J Hum Pharmacol Drug Ther 28:469-484, 2008

8. Hall ED: High-dose glucocorticoid treatment improves neurological recovery in head-injured mice. $J$ Neurosurg 62:882-887, 1985

9. Hartwell RC, Sutton LN: Mannitol, intracranial pressure, and vasogenic edema. Neurosurgery 32:444-450, 1993

10. Ikeda Y, Long DM: The molecular basis of brain injury and brain edema: The role of oxygen free radicals. Neurosurgery $27: 1-11,1990$

11. Johshita H, Kassell N, Sasaki T: Blood-brain barrier disturbance following subarachnoid hemorrhage in rabbits. Stroke 21:1051-1058, 1990

12. Klatzo I: Neuropathological aspects of brain edema. J Neuropathol Exp Neurol 26:1-14, 1967

13. Korfali E, Ipekoglu Z: Artmi $\S$ intrakranial basine, beyin herniasyonu ve tedavisi. İçinde: Temel Nöroşirürji I. Altinörs N, Baykaner K, Sekercl Z, Özyurt E, Caner H (eds). Ankara: TNDer Yayınevi, 1997:8-16

14. Malcok U, Sengul G, Kadioglu H, Aydin I: Therapeutic effect of vitamin D3 in a rat diffuse axonal injury model. J Int Med Res 33:90-95, 2005

15. Marshall L: Treatment of brain swelling and brain edema in man. Adv Neurol 28:459-469, 1980 
Kul H. et al: The Role of Alpha Lipoic Acid in Traumatic Brain Injury

16. Marshall LF, Maas Al, Marshall SB, Bricolo A, Fearnside M, lannotti F, Klauber MR, Lagarrigue J, Lobato R, Persson L: A multicenter trial on the efficacy of using tirilazad mesylate in cases of head injury. J Neurosurg 89:519-525, 1998

17. McCall J, Braughler J, Hall E: Lipid peroxidation and the role of oxygen radicals in CNS injury. Acta Anaesthesiol Belg 38:373-379, 1987

18. Navari-Izzo F, Quartacci MF, Sgherri C: Lipoic acid: A unique antioxidant in the detoxification of activated oxygen species. Plant Physiol Biochem 40:463-470, 2002

19. Nelson SR: Effect of drugs on experimental brain edema in mice. J Neurosurg 41:193-199, 1974

20. Nortje J, Menon DK: Traumatic brain injury: Physiology, mechanisms, and outcome. Curr Opin Neurol 17:711-718, 2004

21. Packer L, Witt EH, Tritschler HJ: Alpha-lipoic acid as a biological antioxidant. Free Radic Biol Med 19:227-250, 1995

22. Pollay M: Blood-brain barrier, cerebral edema. In: Wilkins $\mathrm{RH}$, Rengachary SS (eds). Neurosurgery. 2 nd ed. New York: Mc Graw Hill Book Co., 1996

23. Rengachary S, Wilkins R: Increased intracranial pressure, cerebral edema, and brain herniation. New York: Wolfe, 1994:2.2-2.14
24. Sakowitz OW, Stover JF, Sarrafzadeh AS, Unterberg AW, Kiening KL: Effects of mannitol bolus administration on intracranial pressure, cerebral extracellular metabolites, and tissue oxygenation in severely head-injured patients. J Trauma Acute Care Surg 62:292-298, 2007

25. Scalfani MT, Dhar R, Zazulia AR, Videen TO, Diringer MN: Effect of osmotic agents on regional cerebral blood flow in traumatic brain injury. J Crit Care 27:526, 2012

26. Semple BD: Early preservation of mitochondrial bioenergetics supports both structural and functional recovery after neurotrauma. Exp Neurol 261:291-297, 2014

27. Senturk S, Gurcay AG, Bozkurt I, Gurcan O, Eroglu H, Turkoglu OF, Bodur E, Bavbek M: Effects of tadalafil-type-V phosphodiesterase enzyme inhibitor-on rats with spinal trauma. Br J Neurosurg 29:254-259, 2015

28. Shackford SR, Zhuang J, Schmoker J: Intravenous fluid tonicity: effect on intracranial pressure, cerebral blood flow, and cerebral oxygen delivery in focal brain injury. J Neurosurg 76:91-98, 1992

29. Skibska B, Józefowicz-Okonkwo G, Goraca A: Protective effects of early administration of alpha-lipoic acid against lipopolysaccharide-induced plasma lipid peroxidation. Pharmacol Rep 58:399-404, 2006

30. Tedavi Yönünden Tıbbi KSR: Farmakoloji 11. baskı. Ankara: Hacettepe Taş Kitapçılık, 2005:209-213 